\title{
Plasma Total Nitric Oxide and Endothelial Constitutive Nitric Oxide Synthase (ecNOS) Inron 4 Gene Polymorphism: A Study in Children with Chronic Kidney Disease
}

\author{
Manal F. Elshamaa ${ }^{1}$, Samar Sabry², Ahmed Badr², Eman A. Elghoroury³, \\ Soulaf Kamel ${ }^{3}$ and Gamila Elsaied ${ }^{4}$ \\ ${ }^{1}$ Pediatric Department, National Research Centre, \\ ${ }^{2}$ Pediatric Department, Faculty of Medicine, Cairo University, \\ ${ }^{3}$ Clinical \& Chemical Pathology Department, National Research Centre, \\ ${ }^{4}$ Medical Biochemistry Department, National Research Centre,
}

Egypt

\section{Introduction}

Considerable progress has been made in the treatment of end-stage renal disease over the past $20 \mathrm{yr}$. Nonetheless, the dialysis population continues to carry an excess mortality from fatal cardiovascular events [Baylis et al., 2006]. One possible explanation derives from the association of uremia and accelerated atherosclerosis [Tripathi et al., 2008]. The latter may be related to pre-dialysis factors such as preceding arterial hypertension, glucose intolerance, secondary hyperparathyroidism, dyslipidemia, and others. However, dialysis itself may further contribute to atherosclerosis by oxidative stress, cytokine stimulation, and other events inherent to hemodialysis (HD). Endothelial dysfunction has been shown recently to be a major initiating factor in atherosclerosis [Kone et al., 1997]. Endothelial dysfunction is associated primarily with decreased nitric oxide (NO). However, endothelial dysfunction of uremia has received little attention.

Among the various factors involved in the deterioration of renal function, changes in the hemodynamic are thought to be important. Nitric oxide (NO), an important endothelium derived relaxing factor, is synthesized in the vascular endothelium by the NO synthase. NO is a potent regulator of intrarenal hemodynamics [Baylis et al., 2006 and Tolins et al., 1990]. At the release site it mediates local vasodilatation, antagonizes platelet aggregation, inhibits vascular smooth muscle cell proliferation and also, regulates some vessel-platelet interactions, limits the oxidation of atherogenic low density lipoproteins and has a vasoprotective effect by scavenging superoxide radicals and suppresses leukocyte adhesion to endothelial vessel wall. Multiple lines of evidence have suggested that NO plays a protective role in various important events during atherogenesis. Reduced NO levels are involved in the pathogenesis of the vascular endothelium due to the loss of its vasodilatory effect [Schmidt et al., 1994]. In the kidney, NO dilates renal blood vessels and modulates renin secretion [Kone et al., 1997 and Tripathi et al., 2008]. An impairment of NO production 
causes abnormalities in vascular function in many diseases including human arterial hypertension and renal disease [Schmidt et al., 2000 and Tang et al., 2008].

The endothelial constitutive NO synthase (ecNOS), which produces NO from L-arginine, is encoded by a gene located on chromosome 7q35-36, expressed in endothelium [Baylis et al., 2006 and Nadaud et al., 1994]. Recently, several studies have shown that the polymorphisms of ecNOS are related to the haemodynamics. There are two alleles identified in intron 4 of the ecNOS gene. The larger allele, $4 \mathrm{~b}$, consists of five tandem $27-\mathrm{bp}$ repeats and the smaller one, 4a, has four repeats [Wang el al., 1999 and Yilmaz et al., 2009].

Several allelic variants of eNOS gene have been identified and their association with human diseases states has been studied. The evidence suggests that NO may inhibit several key steps in the atherosclerosis process and that an alteration in NO production within the vascular endothelium could contribute to pathogenesis of atherosclerosis. Several eNOS gene polymorphisms have been reported as "susceptibility genes" in various cardiovascular (CVD) and pulmonary diseases. GT substitution in exon7 in codon 298, T786 mutation in the 5' flanking region and high numbers of CVD, which have been repeated in intron 13 of eNOS gene are also known to be associated with an excess of risk of coronary artery disease (CAD) [Asakimori et al., 2001]. Among the reported polymorphisms of the eNOS gene, a significant association of the $4 \mathrm{a} / \mathrm{b}$ polymorphism in intron 4 of the eNOS gene with CAD and arterial hypertension has also been reported (Yoon et al.2000).

Ichihara et al., in 1998 observed an association between the ecNOS4a allele and myocardial infarction in both a smoking and non-smoking Japanese population. As both coronary lesions and chronic renal failure are basically vascular disorders, we speculate that the gene polymorphism in ecNOS intron 4 might have some relevance to progression in chronic renal failure.

An association of the $4 \mathrm{a}$ allele of the ecNOS gene with renal disease was reported [Asakimori et al., 2001, Miyamotoet al., 1998 and Thaha et al., 2008]. Chronic renal failure is basically a vascular disorder and investigating ecNOS gene polymorphism might shed some light on the pathophysiology of renal disease and progression to end-stage renal disease (ESRD).

\section{Aim of work}

We investigated (a) the relevance of the ecNOS intron 4 polymorphism to the development and progression of chronic renal failure, (b) its relationship with arterial hypertension and cardiovascular complications in CKD pediatric patients undergoing maintenance hemodialysis (MHD) or conservative treatment (CT).

\section{Subjects and methods}

Seventy eight Egyptian pediatric patients with advanced CKD [stages 4 and 5 based on estimated glomerular filtration rate (eGFR) according to the National Kidney Foundation classification [National Kidney Foundation, 2002], were included in the study (Table 1). They were divided into two groups undergoing CT $(n=32)$ or MHD $(n=46)$. MHD children were selected from the hemodialysis Unit of the Center of Pediatric Nephrology and Transplantation (CPNT), while CT children were selected from the Nephrology Pediatric Clinic, Children's Hospital, Cairo University. The study was done from April 2009 to December 2009. 


\begin{tabular}{|c|c|c|c|}
\hline Stage & Description & $\begin{array}{c}\text { GFR } \\
(\mathrm{mL} / \mathrm{min} \text {. per } 1.73 \mathrm{~m} 2)\end{array}$ & Related terms \\
\hline 1 & $\begin{array}{c}\text { Kidney damage with } \\
\text { normal or } \uparrow \text { GFR }\end{array}$ & $\geq 90$ & $\begin{array}{c}\text { Albuminuria } \\
\text { Proteinuria } \\
\text { Haematuria }\end{array}$ \\
\hline 2 & $\begin{array}{l}\text { Kidney damage } \\
\text { with mild } \downarrow \text { GFR }\end{array}$ & $60-89$ & $\begin{array}{c}\text { Albuminuria } \\
\text { Proteinuria } \\
\text { Haematuria }\end{array}$ \\
\hline 3 & Moderate $\downarrow$ GFR & $30-59$ & $\begin{array}{c}\text { CKD } \\
\text { Early renal } \\
\text { insufficiency }\end{array}$ \\
\hline 4 & Severe $\downarrow$ GFR & $15-29$ & $\begin{array}{c}\text { CKD } \\
\text { Late renal } \\
\text { insufficiency } \\
\text { Pre-ESRD }\end{array}$ \\
\hline 5 & Kidney failure & $5<15$ & $\begin{array}{l}\text { Renal failure } \\
\text { Uraemia } \\
\text { End-stage } \\
\text { renal disease }\end{array}$ \\
\hline
\end{tabular}

Table 1. Classification of chronic kidney disease (National Kidney Foundation, 2002)

In CT patients the causes of renal failure were renal hypoplasia or dysplasia $(n=14)$, obstructive uropathies $(n=8)$, neurogenic bladder $(n=4)$, not known $(n=4)$, or metabolic $(n=2)$. In MHD, the causes of renal failure were hereditary nephropathies $(n=17)$, obstructive uropathies $(n=6)$, neurogenic bladder $(n=2)$, glomerulopathy $(n=2)$, renal hypoplasia or dysplasia $(n=2)$, and unknown causes $(n=17)$. The inclusion criteria for MHD patients included patients with onset of HD below 16 years with at least 6 months duration on MHD. They were treated with hemodialysis for 3-4 h three times weekly with a polysulfone membrane using bicarbonate-buffered dialysate. The duration of hemodialysis was 2.75 \pm 1.59 years. Measurement of HD adequacy was as follows: the delivered dose of HD was described as the fractional clearance of urea as a function of its distribution volume $(\mathrm{Kt} / \mathrm{V})$ and was determined by using the $\mathrm{Kt} / \mathrm{V}$ natural logarithm formula according to the equation

$$
\mathrm{Kt} / \mathrm{V}=\mathrm{Ln}(\mathrm{R}-0.008 \mathrm{xt})+(4-3.5 \mathrm{R}) \mathrm{UF} / \mathrm{W}
$$

Where $\mathrm{Ln}=$ natural logarithm, $\mathrm{R}=$ post-dialysis $\mathrm{BUN} /$ pre-dialysis $\mathrm{BUN}$. $\mathrm{t}=$ dialysis session length in hours, $\mathrm{UF}=$ ultrafiltration volumes in liters. $\mathrm{W}=$ patients post-dialysis weight in kilogram.

Thirty two MHD patients and $16 \mathrm{CT}$ patients were taking antihypertensive treatment. The following classes of drugs were employed: $a$-adrenoceptor antagonists in two MHD and two $\mathrm{CT}, \beta$-blockers in nine MHD, ACE inhibitors in seventeen MHD, and six CT patients and Ca channel blockers in twenty-nine MHD and ten CT patients. Subjects were taking their medication when ACE activity was measured and no influence of medication on the measurement.

All control subjects $(n=30)$ were healthy with no clinical signs of vascular or renal disease and no family history of renal disease, as well as lack of medications taken at the time of the 
study. Control subjects were selected to be matched for age and gender to the patient groups, as well as within the same BMI limits. They were collected from the pediatric clinic of National Research Centre (NRC), Cairo, Egypt. An informed consent for genetic studies was obtained from parents of all participants. The protocol of the study was read and approved by the Ethics Committee of NRC in Egypt.

\subsection{Diagnostic criteria of vascular disease}

We studied the prevalence of vascular disease in children with CKD according to the following criteria [Kimura et al. 1999].

Cardiac disease: the presence of primary dilated cardiomyopathy previously diagnosed clinically and by echocardiography.

Cerebral vascular disease: cerebral vascular disease was suspected on clinical grounds, i.e., rapidly developing signs of focal disturbance of cerebral function such as hemiparesis and hemisensory impairment. The diagnosis was confirmed by computed tomography or magnetic resonance imaging. Brain hemorrhage and subarachnoid hemorrhage were excluded.

A patient was considered to have a vascular disease when at least one of these two defined vascular disease was present.

\subsection{Biochemical markers}

Venous blood samples were collected in the morning after an overnight fast on a midweek dialysis day, before the dialysis session. Three $\mathrm{ml}$ of venous blood sample was collected in EDTA vials for the extraction of genomic DNA. Complete blood count and pre- and postdialysis kidney function test were determined by standard laboratory methods. Estimations of the plasma concentration of total cholesterol (TC), triglyceride (TG) and HDL cholesterol were made by using an Olympus AU400 (Olympus America, Inc., Center Valley, Pa., USA).

\subsection{Quantitative determination of nitric oxide concentration in serum}

It is done by using the Griss reaction after ultrafiltration via the immunosorbent assay (R\&D system. Inc. Minneapolis, MN55413, USA) [Tsikas, 2005] .

\subsection{Determination of ecNOS genotype}

DNA was extracted from peripheral blood using a QIAamp Blood miniprep extraction Kit (QIAGEN, Germany) and was stored at $4^{\circ} \mathrm{C}$ until analysis. eNOS genotypes were determined by the polymerase chain reaction (PCR). Briefly, the oligonucleotide primers (the forward primer sequence was 5'-AGGCCCTATGGTAGTGCCTTT -3' which was located at position 5111-5130 base pairs of the genomic sequence of NOS, and the sequence of the reverse primer was 5'-TCTCTTAGTGCTGT GGTCAC-3' which its position within the genomic sequence of NOS was 5530-5511 bp) that flank the region of the 27-bp direct repeat in eNOS intron 4 were used for DNA amplification [Salimi et al., 2006]. Each reaction mixture was heated to $94^{\circ} \mathrm{C}$ for 4 min for denaturation and underwent 35 cycles at $94^{\circ} \mathrm{C}$ for one min, annealing at $56^{\circ} \mathrm{C}$ for one min with an extension at $72^{\circ} \mathrm{C}$ for two min, and a final extension at $74^{\circ} \mathrm{C}$ for seven min. The PCR products were analysed by $2 \%$ agarose gel electrophoresis and fragments were visualized by ethidium bromide staining and ultraviolet transillumination [Figure 1]. 


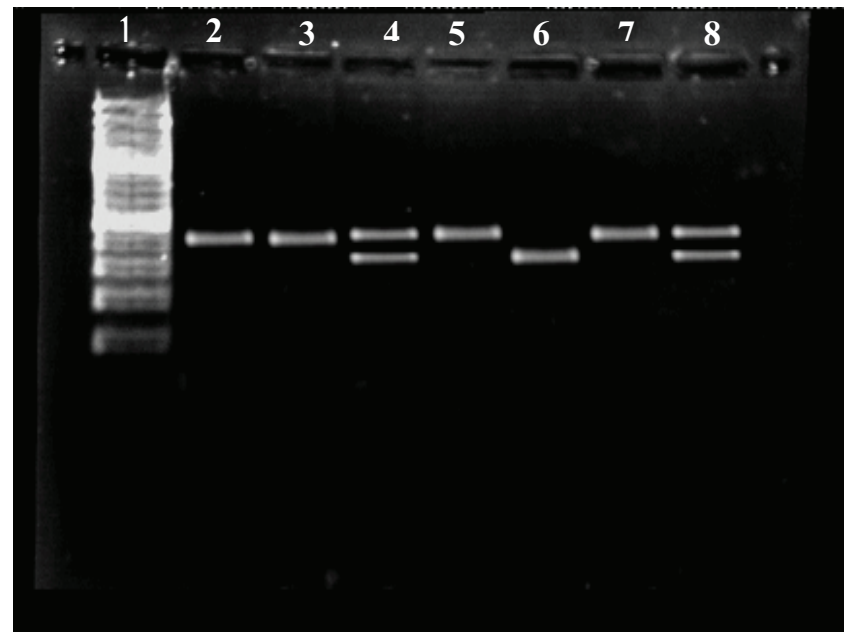

Lanes $(2,3,5 \& 7)$ show a single band at $420 \mathrm{bp}$ representing the homozygous allele B pattern (NOSB/B). Lanes $(4 \& 8)$ represent the heterozygous pattern for allele A and allele $B\left(\operatorname{NOS}^{A / B}\right)$.

Lane (6) shows one band at 393bp representing the homozygous allele A pattern (NOS $\left.{ }^{A / A}\right)$. Lane 1 denotes molecular weight ladder marker 100-1000bp (Sigma, St. Louis, USA).

Fig. 1. Genotyping of NOS polymorphism photographed on a $2 \%$ agarose gel electrophoresis resolving the wild type allel B at $420 \mathrm{bp}$ and the polymorphic allele A at 393bp.

\subsection{Statistical analysis}

Statistical package for social science (SPSS) program version 11.0 was used for analysis of data. Data were summarized as mean $\pm S D$, range or percentage. Histograms and normality plots were used for evaluating the normality of data. For those data with abnormal distribution, $\log$ transformation was performed before a t-test. The number of subjects required for each subgroup was determined by survey sampling basics: Analytical Plan, Population Variability \& Confidence Intervals. Data were valuated between the experimental groups by One-Way Analysis of Variance (ANOVA) followed by Tukey's multiple comparison test. Allele and genotypic frequencies for ecNOS alleles were calculated with the gene counting method. Hardy-Weinberg equilibrium was tested with the $X^{2}$ test. Comparison of the categorical data i.e. different ecNOS genotypes among patients was done by independent-samples $t$ test where appropriate after evaluating the normality of data. Fisher's exact test and $X^{2}$ test were done to confirm the results. . Multiple regression analysis was performed to assess the influence of ecNOS alleles on hypertension and vascular diseases. A p value of $<0.05$ was considered significant.

\section{Results}

Clinical and biochemical characteristics of the studied groups were summarized in Table 2. There were no significant differences between groups with respect to age, gender ratio and total serum cholesterol level. Serum NO level was significantly higher in both MHD 
and CT groups than the controls and the level was significantly higher in MHD group than CT group $(143.93 \pm 35.99 \mu \mathrm{mol} / \mathrm{L}, \quad 91.48 \pm 28.80 \mu \mathrm{mol} / \mathrm{L}, \quad 51.84 \pm 12.39 \mu \mathrm{mol} / \mathrm{L}$, respectively).

The distribution of genotypes and allele frequencies were compared between patients and controls (Table 3). The genotype frequencies were in agreement with Hardy-Weinberg equilibrium. The Hardy-Weinberg equation is in the following form

$$
p^{2}+2 p q+q^{2}=1
$$

Where $\mathrm{p}$ is the frequency of the $\mathbf{A}$ allele in the population and $\mathrm{q}$ is the frequency of the a allele in the population.

The frequencies of genotypes in the population are given by

- $\mathrm{p}^{2}$ for genotype $\mathbf{A A}$,

- 2pq for genotype Aa,

- $\mathrm{q}^{2}$ for genotype aa.

Dialyzed and CT patients had significantly higher frequency of the aa genotype and ecNOS4a allele $(\mathrm{P}<0.05)$ compared with control subjects. The multiple logistic regression analysis with correction for age and sex revealed that the frequency of the ecNOS4a allele carriers was significantly higher in dialysed and CT patients than in healthy subjects. There was no significant difference between MHD and CT groups as regard to aa genotype $(\mathrm{p}>0.05)$.

Comparing clinical and biochemical characteristics of carriers of the ecNOS 4a allele (aa+ab genotypes) and non carriers (bb genotype) were shown in Table 4 . Hypertensive \% was found to be higher in carriers of the ecNOS 4 a allele than in non carriers - bb genotype (85.95\% vs $60.67 \%$, $\mathrm{p}=0.04)$. Also, cardiovascular \% was significantly higher in carriers of the ecNOS $4 \mathrm{a}$ allele than in non carriers - bb genotype-, ( $35.90 \%$ vs $5.13 \%, \mathrm{p}=0.01$ ). There were significant differences between the two subgroups as regard to triglycerides and HDL cholesterol $(190.00 \pm 57.15 \mathrm{mg} / \mathrm{dL}$ vs $116.25 \pm 48.49 \mathrm{mg} / \mathrm{dL}, \mathrm{p}=0.02$ and $21.22 \pm 7.05 \mathrm{mg} / \mathrm{dlL}$ vs $32.00 \pm 15.96 \mathrm{mg} / \mathrm{dL}, \mathrm{p}=0.03$, respectively). Serum $\mathrm{NO}$ level was found to be lower in carriers of the ecNOS 4a allele than in non carriers $(100.29 \pm 27.32(\mu \mathrm{mol} / \mathrm{L})$ vs $152.73 \pm 60.39(\mu \mathrm{mol} / \mathrm{L})$, $\mathrm{p}=0.04)$.

To examine the survival bias in evaluating the effect of the ecNOS4 polymorphism on renal disease, we analyzed allele and genotype frequencies in MHD subjects shorter than 3 years on dialysis and those dialyzed 3 years or longer (data not shown). There were no statistically significant differences between these two groups $(\mathrm{p}=\mathrm{NS})$, suggesting little or no influence of survival bias on the outcome of the study.

We performed a multiple linear regression analysis with backward stepwise selection using all the clinical risk factors for hypertension and the mutant allele of the eNOS 4 a gene. This analysis revealed that the most predictive independent risk factors for hypertension were the mutant allele $(B=0.50, p=0.03)$, NO level $(\beta=-0.47, p=0.03)$ and TG $(\beta=0.60, p=0.02)$ in Table 5.

A multiple linear regression analysis using a model identical to the one used to test hypertension was used to test vascular disease for the relationship with the mutant allele of the eNOS 4 a gene. This analysis suggested that the allele has a dominant effect on the risk of vascular complications in these children $(\beta=0.99, \mathrm{p}=0.04)$ in Table 6 . 
Plasma Total Nitric Oxide and Endothelial Constitutive Nitric Oxide Synthase (ecNOS) Inron 4 Gene Polymorphism: A Study in Children with Chronic Kidney Disease

\begin{tabular}{|c|c|c|c|}
\hline & $\begin{array}{c}\text { CT } \\
(\mathrm{n}=32)\end{array}$ & $\begin{array}{c}\text { MHD } \\
(\mathrm{n}=46)\end{array}$ & $\begin{array}{c}\text { Controls } \\
(\mathrm{n}=30)\end{array}$ \\
\hline Age & $9.14 \pm 7.59$ & $10.62 \pm 3.49$ & $8.7 \pm 4.51$ \\
\hline Gender $(\mathrm{M} / \mathrm{F})$ & $\begin{array}{c}15 \\
(46.88 \%) / 17(53.12 \%)\end{array}$ & $25(54.35 \%) / 21(45.65 \%)$ & $20(66.67 \%) / 10(33.33 \%)$ \\
\hline SBP $(\mathrm{mmHg})$ & $98.66 \pm 6.66$ & $127.13 \pm 18.37 \mathrm{~b}^{*}$ & $94.55 \pm 9.80$ \\
\hline DBP $(\mathrm{mmHg})$ & $64.66 \pm 6.67$ & $85.15 \pm 13.7 \mathrm{~b}^{\mathrm{b}^{*}}$ & $60.59 \pm 10.11$ \\
\hline $\begin{array}{c}\text { Creatinine } \\
(\mathrm{mgdL})\end{array}$ & $3.93 \pm 3.75 \mathrm{a}^{*}$ & $6.32 \pm 1.55^{\mathrm{b}^{*}}$ & $0.77 \pm 0.34$ \\
\hline $\begin{array}{c}\text { Predialysis } \\
\text { urea }(\mathrm{mg} / \mathrm{dL})\end{array}$ & $51.12 \pm 10.45^{\mathrm{a}^{*}}$ & $71.56 \pm 20.61 \mathrm{~b}^{*}$ & $7.80 \pm 2.64$ \\
\hline $\begin{array}{c}\text { Dialysis, Yrs } \\
\text { Kt/V }\end{array}$ & $164.44 \pm 50.10$ & $193.04 \pm 51.37 \mathrm{~b}^{*}$ & $160.31 \pm 18.74$ \\
\hline $\begin{array}{c}\text { Total } \\
\text { cholesterol } \\
(\mathrm{mg} / \mathrm{dL})\end{array}$ & $160.78 \pm 57.33 \mathrm{a}^{* *}$ & $147.00 \pm 66.98 \mathrm{~b}^{* *}$ & $65.31 \pm 18.35$ \\
\hline $\begin{array}{c}\text { Triglycerides } \\
(\mathrm{mg} / \mathrm{dL})\end{array}$ & $21.35 \pm 1.17 \mathrm{a}^{*}$ & $27.34 \pm 9.88 \mathrm{~b}^{*}$ & $39.55 \pm 7.94$ \\
\hline $\begin{array}{c}\mathrm{HDL} \\
\text { cholesterol } \\
(\mathrm{mg} / \mathrm{dL})\end{array}$ & $91.48 \pm 28.80^{\mathrm{a}^{*}}$ & $143.93 \pm 35.99 \mathrm{~b}^{* *} \mathrm{c}$ & $51.84 \pm 12.39$ \\
\hline $\begin{array}{c}\text { Serum NO } \\
\text { level }(\mu \mathrm{mol} / \mathrm{L})\end{array}$ & $1.69 \pm 0.42$ & \\
\hline
\end{tabular}

Data was evaluated by ANOVA test. Values are presented as means $\pm \mathrm{SD}$ or percentage as applicable. $\mathrm{CT}=$ conservative treatment, $\mathrm{MHD}=$ maintenance hemodialysis, $\mathrm{SBP}=$ systolic blood pressure, $\mathrm{DBP}=$ diastolic blood pressure, $\mathrm{Kt} / \mathrm{V}=$ adequacy of hemodialysis, ${ }^{*} \mathrm{P}<0.05$ or ${ }^{\mathrm{a} *}{ }^{*} \mathrm{P}<0.01$ vs controls and $\mathrm{CT}^{\mathrm{b} * \mathrm{P}<0.05 \text { or }}{ }^{\mathrm{b} * *} \mathrm{P}<0.01$ vs control and MHD, $\mathrm{P}<0.01$ vs $\mathrm{CT}$ and MHD.

Table 2. Clinical and biochemical data of the studied groups

\begin{tabular}{|c|c|c|c|c|}
\hline \multicolumn{2}{|c|}{ Gene } & $\begin{array}{c}\text { CT } \\
(\mathrm{n}=32)\end{array}$ & $\begin{array}{c}\text { MHD } \\
(\mathrm{n}=46)\end{array}$ & $\begin{array}{c}\text { Controls } \\
(\mathrm{n}=30)\end{array}$ \\
\hline \multirow{3}{*}{ Alleles } & $\mathrm{b}$ & $43(67.19 \%)$ & $61(66.30 \%)$ & $47(78.33 \%)$ \\
\cline { 2 - 5 } & $\mathrm{a}$ & $21(32.81 \%)$ & $31(33.70 \%)^{\mathrm{b}}$ & $13(22.67 \%)$ \\
\hline \multirow{3}{*}{ Genotypes } & $\mathrm{bb}$ & $16(50 \%)$ & $23(50.00 \%)$ & $17(56.67 \%)$ \\
\cline { 2 - 5 } & $\mathrm{ab}$ & $11(34.38 \%)$ & $15(32.61 \%)$ & $13(43.33 \%)$ \\
\cline { 2 - 5 } & $\mathrm{aa}$ & $5(15.62 \%)^{\mathrm{a}}$ & $8(17.39 \%)^{\mathrm{b}}$ & $0(0.00 \%)$ \\
\hline
\end{tabular}

Data was evaluated by the gene counting method. Values are presented as percentage. $\mathrm{CT}=$ conservative treatment, $\mathrm{MHD}=$ maintenance hemodialysis.

${ }^{a} \mathrm{p}<0.05$ vs control and CT

b $p<0.05$ vs control and MHD

Table 3. Frequencies of ecNOS intron 4 genotypes in patients and controls 


\begin{tabular}{|c|c|c|c|}
\hline & $\begin{array}{c}\mathrm{aa}+\mathrm{ab} \\
(\mathrm{n}=39)\end{array}$ & $\begin{array}{c}\mathrm{bb} \\
(\mathrm{n}=39)\end{array}$ & P value \\
\hline Age & $11.66 \pm 4.77$ & $9.33 \pm 3.25$ & $\mathrm{NS}$ \\
\hline SBP(mmHg) & $120.25 \pm 22.47$ & $114.00 \pm 15.95$ & $\mathrm{NS}$ \\
\hline DBP(mmHg) & $79.37 \pm 13.40$ & $77.47 \pm 13.80$ & $\mathrm{NS}$ \\
\hline Hypertensive\% & $85.95 \%$ & $60.67 \%$ & $0.04^{*}$ \\
\hline Cardiovascular disease $\%$ & $14(35.90 \%)$ & $2(5.13 \%)$ & $0.01^{*}$ \\
\hline Total cholesterol $(\mathrm{mg} / \mathrm{dl})$ & $183.00 \pm 38.96$ & $180.00 \pm 68.67$ & $\mathrm{NS}$ \\
\hline Triglycerides $(\mathrm{mg} / \mathrm{dl})$ & $190.00 \pm 57.15$ & $116.25 \pm 48.49$ & $0.02^{*}$ \\
\hline HDL-cholesterol $(\mathrm{mg} / \mathrm{dl})$ & $21.22 \pm 7.05$ & $32.00 \pm 15.96$ & $0.03^{*}$ \\
\hline Creatinine $(\mathrm{mg} / \mathrm{dl})$ & $5.99 \pm 2.06$ & $5.44 \pm 2.15$ & $\mathrm{NS}$ \\
\hline Predialysis urea $(\mathrm{mg} / \mathrm{dl})$ & $69.88 \pm 27.84$ & $67.00 \pm 23.01$ & $\mathrm{NS}$ \\
\hline Serum NO level $(\mu \mathrm{mol} / \mathrm{l})$ & $100.29 \pm 27.32$ & $152.73 \pm 60.39$ & $0.04^{*}$ \\
\hline
\end{tabular}

Significance was estimated using independent t-test. Data are means \pm SD. SBP=systolic blood pressure, $\mathrm{DBP}=$ diastolic blood pressure, $\mathrm{NO}=$ nitric oxide, $\mathrm{p}$ is significant if $<0.05, \mathrm{NS}=$ non significant.

Table 4. Clinical characteristics of CKD patients with different ecNOS intron 4 genotypes

\begin{tabular}{|c|c|c|}
\hline & $\Re$ & P value \\
\hline Age & 0.06 & NS \\
\hline Triglycerides $(\mathrm{mg} / \mathrm{dl})$ & 0.60 & $0.02^{*}$ \\
\hline Serum NO level $(\mu \mathrm{mol} / \mathrm{l})$ & 0.47 & $0.03^{*}$ \\
\hline Mutant allele $($ a allele $)$ & 0.50 & $0.03^{*}$ \\
\hline
\end{tabular}

$\mathrm{NO}=$ nitric oxide, $\mathrm{P}<0.05$ was considered significant

Table 5. Risk factors affecting hypertension in CKD patients based on multiple linear regression analysis

\begin{tabular}{|c|c|c|}
\hline & $\mathbb{1}$ & P value \\
\hline Age & 0.07 & NS \\
\hline Hypertension $\%$ & 0.60 & $0.02^{*}$ \\
\hline SBP & 2.19 & $0.03^{*}$ \\
\hline DBP & 2.60 & $0.02^{*}$ \\
\hline Serum NO level $(\mu \mathrm{mol} / \mathrm{l})$ & 0.41 & $0.03^{*}$ \\
\hline Mutant allele $($ a allele) & 0.99 & $0.04^{*}$ \\
\hline
\end{tabular}

$\mathrm{SBP}=$ systolic blood pressure, $\mathrm{DBP}=$ diastolic blood pressure, $\mathrm{NO}=$ nitric oxide, $\mathrm{p}<0.05$ was considered significant.

Table 6. Risk factors affecting cardiovascular disease in CKD patients based on multiple linear regression analysis. 


\section{Discussion}

Chronic renal failure is a multifactorial disease with different prevalence and clinical phenotype in different populations. This study is an attempt to describe the functional state of the NO system in patients on chronic HD, using carefully matched control subjects.

More than $99 \%$ of human DNA sequences are the same across the population, however, variations in DNA sequence can have a major impact on how humans respond to environmental insults such as toxins. The single nucleotide polymorphisms (SNPs) or snips are DNA sequence variations that occur when a single nucleotide in the genome sequence is altered. A point mutation is considered as SNP if it occurs in at least in $1 \%$ of the population. The SNPs are responsible for about $90 \%$ of all human genetic variation and occur every 100 300 bases along the 3-billionbases of human genome both in coding and non-coding regions. Two-third of known SNPs involves the replacement of cytosine with thymine. The SNPs that have no effect on cell function could predispose people to disease or influence their response to a toxicant [Agarwal et al., 2003].

Gene and environment play a critical role in many genetic disorders of multi-factorial origin. Epidemiological studies have shown statistically significant association of several factors among which genetic susceptibility is the common factor as indicated by familial aggregation and greater concordance in monozygotic twins with the onset of the diseases such as obesity, cancer, hypertension, and diabetes [Agarwal et al.,2003]. The PCR- and sequencing-based techniques have been used to assess the presence of SNPs in a particular gene. Genome-environment interaction among individuals for the susceptibility to a disease greatly varies and Fosmid library allele-specific haplotypes analysis (FLASH) and large insert genome analysis (LIGA) has improved the understanding of genetic variations in various populations.[Kaul, 2003] FLASH allows to isolate and sequence fosmid clones that tile a given loci in a haplospecific manner over along genomic region of interest and LIGAN allows the use of end sequence and fingerprint data to identify the variant genomic regions from multiple individuals.[ Kaul, 2003] FLASH and LIGAN have overcome the limitations of PCR-based re-sequencing methods to screen thousands of individuals [Agarwal et al., 2003] .FLASH does not provide phase information for the underlying haplotypes structure of a diploid genome and LIGAN provides a limited resolution at the chromosome level.[Kaul, 2003]. Telomeric repeat amplification protocol (TRAP), a sensitive, high throughput PCR-based assay provides a reliable tool for the experiments that requires massive quantitation of telomerase activity, however, a pyraseme diated allele-specific extension reaction (AMASE) is a novel tool used for microarray-based mutation detection and allows the simultaneous, efficient, and accurate analysis of several samples from different stages of skin malignancies [Kaller et al., 2004].

In this study the frequency of a allele in the ecNOS intron 4 was significantly higher in both dialyzed and CT patients compared with in healthy controls indicating that the ecNOS $4 \mathrm{a}$ allele is a risk factor for ESRD in children with CKD. Such an association was observed earlier by others. Asakimori et al, in 2001, found a significantly higher frequency of the ecNOS 4a allele in haemodialysis patients, both non-diabetic and diabetic, and therefore suggested that the polymorphism in intron 4 of the ecNOS gene may have influence on the progression of renal disease. Wang et al, in 1999, in their study of 302 subjects with endstage renal disease and 248 healthy controls found a significantly higher frequency of the ecNOS 4a allele in patients with ESRD caused by non-diabetic primary renal diseases. Freedman et al.2000 evaluated the role of four NOS gene polymorphisms in ESRD patients 
and found that the a allele of the ecNOS 4 polymorphism in the NOS gene was associated with all-cause ESRD in probands and their siblings compared with healthy subjects.

One study showed that the basal concentration of NO metabolites (nitrate plus nitrite) in the plasma was reduced in individuals with essential hypertension [Asakimori et al., 2001 and Yilmaz et al., 2009]. Tsukada et al.,1998 reported a strong association between the a allele of the ecNOS gene and the plasma NOx (nitrate and nitrite) levels.

In our study, there was a significant elevation of serum NO levels in patients with CKD either on MHD or on CT than the controls and the level was significantly higher in MHD group than CT group. Nitric oxide, an extensively studied endothelium relaxing factor, is reported to be a very potent regulator of intrarenal hemodynamics [Kerkeni et al., 2009 and Möllsten et al., 2009] . It plays a major role in the regulation of cardiovascular homeostasis both in health and disease. Many studies have published the relation between NO and renal failure. An impaired response to NO may contribute to the initiation or maintenance of the increased intra-glomerular high pressure state. The impaired response to NO appeared more in MHD patients as they are to exposed to increased oxidative stress and this may explain the higher level in this group [Nguyen-Khoa et al., 2001].

In the present study, serum NO level was found to be lower in carriers of the ecNOS 4a allele than in non carriers. Gururajan et al., (2010) reported a strong association between the a allele of the ecNOS gene and the plasma NOx (nitrite and nitrate) levels. The mean plasma level of NOx of the subjects who were homozygous for a allele was nearly $20 \%$ lower than in the subjects with the $\mathrm{b}$ allele. Although it is disputable whether the NO metabolites in the blood are derived entirely from ecNOS in the endothelial cells of the blood vessels, it is in fact that plasma NO levels are different depending on ecNOS gene polymorphism. They concluded therefore that the ecNOS gene locus might be responsible for variations in the genetic control of plasma NOx. Failure of vascular endothelium to elicit NO-mediated vasodilation may be due to decreased formation, increased degradation, decreased sensitivity to nitric oxide formed, or a mixture of these factors. Decreased levels of nitric oxide may also be due to the increased activity of the enzyme myeloperoxidase, which consumes nitric oxide as a substrate and also promotes endothelial dysfunction.

The molecular mechanism by which ecNOS gene polymorphism acts to affect the occurrence of ESRD is not known, and it is also unclear whether this polymorphism is a causative variant or a marker of another functional variant. However, the fact that the distribution of a allele in the ecNOS intron 4 showing a significantly higher incidence in children with CKD and plasma NO metabolite levels are reported to be different in depending on ecNOS gene polymorphism, suggests that the ecNOS intron 4 is a useful marker for studying the relationship between NO and the progression of renal disease.

The subjects of the MHD group have been dialyzed for relatively long periods. Therefore we examined the survival bias. The frequencies of ecNOS intron 4gene polymorphism in the long dialysis period group did not differ from those in the short period group. It appears therefore, that neither death nor survival is factors in estimating the role of gene polymorphism in disease progression.

In this study, hypertensive \% was found to be higher in carriers of the ecNOS 4a allele than in non carriers (bb genotype) and on correlating the diastolic blood pressure (DBP) to the a allele and other individual variables by multiple linear regression analysis, the a allele, NO level and TG concentration were variables that were independently associated with DBP $(p<0.05)$. In a study using mice with disrupted eNOS gene revealed that eNOS function is 
required for vascular and hemodynamic responses to acetylcholine and that the disruption of the eNOS gene leads to hypertension [Huang et al., 1995 and Tripathi et al. 2008]. Clinical and experimental studies suggest that an alteration in nitric oxide (NO) metabolism may be a contributing factor in the pathogenesis of hypertension. Thus, abnormalities in the activity of the enzyme endothelial NO synthase (eNOS) that synthesizes NO in endothelial cells may lead to NO abnormality with severe consequences.[Möllsten et al., 2009]. Inhibition of eNOS elevates blood pressure in healthy humans [Haynes et al., 1993]. Furthermore, NO production is diminished in patients with essential hypertension, under basal conditions [Forte et al., 1997 and Möllsten et al., 2009].

Our study revealed that the cardiovascular disease \% was significantly higher in carriers of the ecNOS 4a allele than in non carriers (bb genotype) and that the allele has a dominant effect on the risk of vascular complications in children with CKD by multiple linear regression analysis. Apart from controlling the coronary blood flow, there is now an emerging consensus that NO generally acts to fine-tune and optimize cardiac pump function [Cotton et al., 2002]. Excessive NO depresses systolic function by decreasing myocardial contractility and shortening the ejection period [Cotton et al., 2002]. Elevated circulating levels of oxidative products of (NOx) and myocardial NO synthetase expression have been seen in patients with heart failure due to contractile dysfunction [Balat et al., 2003 and Kerkeni et al., 2009]. We had a previous study on the relation between plasma NO level and left ventricular diastolic function and its etiology in heart failure patients in the pediatric age group. We performed echocardiographic Doppler studies in 47 patients with congestive heart failure. Left ventricular diastolic dysfunction was classified as either a restrictive (RFP) or non restrictive filling pattern (non-RFP). Plasma NOx level was significantly higher in the studied patients than the control group. Plasma NOx levels are elevated in patients with isolated diastolic heart failure, in addition, in patients with LV systolic failure, the severity of LV diastolic dysfunction determines the amount of NO production [Elshamaa et al., 2006]. Many studies reported a correlation of this polymorphism with vascular diseases [Mitsuke et al., 2001, Thibaud et al., 2004 and Wasson et al., 2004].

The intron $4 \mathrm{ab}$ insertion/deletion genotype was associated with isolated lacunar infraction. Protective effect of the $4 \mathrm{a}$ variant could be mediated through changes in eNOS promoter activity and increased NO levels has been suggested through Haplotype and functional studies [Hoffmann et al., 2000]. Another study by Markus et al., 1998 of a Turkish population has shown that carriers of the minor ' $a$ ' allele of intron 4 VNTR had significantly elevated risk for stroke (a). An over representation of $4 \mathrm{c}$ allele of intron 4 VNTR in ischemic stroke patients was suggested in a study involving African American population. In pooled analysis of all patients, intron $4 \mathrm{c}$, but not intron $4 \mathrm{a}$, intron $4 \mathrm{~b}$, or $894 \mathrm{G} / \mathrm{T}$ alleles are associated with stroke. In subgroup analysis by race, the intron $4 \mathrm{c}$ allele is most strongly associated with large artery ischemic stroke in African Americans [Yemişçi et al., 2009]. The association of SNP in exon 7 with stroke was seen only in the study of Hoffmann et al., 2000, while other studies indicated negative finding in white population. Further more Hingorani et al. (1999) also measured carotid stiffness in stroke patients and found it was unrelated to the exon 7 variant.

The limitation of this study includes the small sample size as we collected cases from one centre. Thus, a large number of patients and controls need to be examined to confirm the association of this polymorphism in the Egyptian pediatric population. 


\section{Conclusion}

A allele of the ecNOS intron 4 gene polymorphism showed a significantly higher frequency in children with CKD, both on MHD and CT. These results suggested that the ecNOS gene polymorphism could serve as a useful genetic marker for evaluation of susceptibility to chronic renal failure. Plasma NO levels showed a significant decrease in aa alleles patients and also could independently predict the risk. However, the interactions between this genetic predisposition and environmental factors as well haplotype analysis require further studies. A large number of patients and controls need to be examined to confirm the association of this polymorphism in the Egyptian pediatric population.

\section{Acknowledgment}

This study was supported by the scientific research funds of National Research Centre in Egypt.

\section{References}

Agarwal SS. Causation and susceptibility to disease, International symposium on molecular toxicology and environmental health, Lucknow. 2003, Nov 5-8.

Asakimori Y, Yorioka N, Yamamoto I et al. Endothelial nitric oxide synthase intron 4 polymorphism influences the progression of renal disease. Nephron 2001; 89: 219223

Balat A, Cekmen M, Yurekli M, Yilmaz K, Sahinoz S. Adrenomodulin and nitrite in children with dilated cardiomyopathy. Pediatric Cardiol 2003; 24:381-5

Baylis C. Arginine, arginine analogs and nitric oxide production in chronic kidney disease. Nat Clin Pract Nephrol. 2006 Apr;2(4):209-20.

Cotton JM, Kearney MT, Shah AM. Nitric oxide and myocardial function in heart failure: friend or foe? Heart 2002; 88: 564-6.

Elshamaa M. F., Sharaf E. A, Farid Y. A., Elghoroury E. A , Abdelghaffar E. Plasma Nitric Oxide Level in Myocardial Disorders with Left Ventricular Diastolic Dysfunction. J Clin Basic Cardiol 2006, 9(Issue1-4), (Online) 23-26

Forte P, Copland M, Smith LM, Milne E, Sutherland J, Benjamin N: Basal nitric oxide synthesis in essential hypertension. Lancet 1997; 349:837-42

Freedman BI, Yu H, Anderson PJ, Roh BH, Rich SS, Bowden BW. Genetic analysis of nitric oxide and endothelin in end-stage renal disease. Nephrol Dial Transplant 2000; 15 (11): 1794-1800

Gururajan P, Gurumurthy P , Victor D ,RaoG. S N , Babu R. S, Bharati A S, Cherian K. M. Plasma Total Nitric Oxide and Endothelial Constitutive Nitric Oxide Synthase (ecNOS) Gene Polymorphism:A Study in a South Indian Population. Biochem Genet 10528, 2010; 9391-7

Haynes WG, Noon JP, Walker BR, Webb DJ: Inhibition of nitric oxide synthesis increases blood pressure in healthy humans .J Hypertens 1993, 11:1375-80

Hingorani AD, Liang CF, Fatibebe J, et al. A common Variant of the endothelial nitric oxide synthase (Glu-Asp) is a major risk factor for coronary artery disease in the UK Circulation 1999; 100: 1515-1520 
Hoffmann MM, Winkelmann BR, Schneider S, et al. Endothelial nitric oxide synthase gene Glu298 >Asp variant-Association with arterial hypertension, but not with coronary artery disease. Atherosclerosis 2000; 151: 254.(only one page)

Huang PL, Huang Z, Mashimo H, Bloch KD, Moskowitz MA, Bevan JA, Fishman MC: Hypertension in mice lacking the gene for endothelial nitric oxide synthase. Nature 1995, 377:239-42

Ichihara S, Yamada Y, Fujimura T, Nakashima N,. Yokota M. Association of a eNOS gene polymorphism in myocardial infarction in the Japanese population. Am J Cardiol 1998; 18: 83-6

Kaller M, Ahmadian A, Lundeberg J. Microarray-based AMASE as a novel approach for mutation detection. Mut Res 2004; 554:77-88

Kaul R. Technologies for studying long range and genome wide genetic variation among population of interest, International symposium on molecular toxicology andenvironmental health, Lucknow. 2003, November 5-8.

Kerkeni M, Letaief A, Achour A, Miled A, Trivin F, Maaroufi K. Endothelial nitric oxide synthetase, methylenetetrahydrofolate reductase polymorphisms, and cardiovascular complications in Tunisian patients with nondiabetic renal disease. Clin Biochem. 2009 Jul; 42(10-11):958-64

Kimura H, Gejyo F, Yamaguchi T et al. Cholesteryl ester transfer protein gene mutation and vascular disease in dialysis patients. J Am Soc Nephrol 1999; 10:294-9

Kone BC, Baylis C. Biosynthesis and homeostatic roles of nitric oxide in the normal kidney. Am J Physiol 1997; 272: F561-F578.

Markus HS, Ruigrok Y, Ali N, et al. Endothelial nitric oxide synthase exon 7 polymorphism, ischemic cerebrovascular disease, and carotid atheroma. Stroke 1998; 29:1908-11

Mitsuke Y, Lee JD, Shimizu H, Uzui H, Iwasaki H, Ueda T. Nitric oxide synthase activity in peripheral polymorphonuclear leukocytes in patients with chronic congestive heart failure. Am J Cardiol 2001; 87: 183-7

Miyamoto Y, Saito Y, Kajiyama N Yoshimura M, Shimasaki y . Endothelial nitric oxide synthase gene is positively associated with essential hypertension. Hypertension 1998; 32: 3-8

Möllsten A, Lajer M, Jorsal A, Tarnow L.The endothelial nitric oxide synthase gene and risk of diabetic nephropathy and development of cardiovascular disease in type 1 diabetes. Mol Genet Metab. 2009 May; 97(1):80-4

Nadaud S, Bonnardeaux A, Lathrop M, Soubrier F. Gene structure, polymorphism and mapping of the human endothelial nitric oxide synthase gene. Biochem Biophys Res Commun1994; 198: 1027-1033.

National Kidney Foundation. K/DOQI clinical practice guidelines for chronic kidney disease: evaluation, classification, and stratification. Am J Kidney Dis 2002, 39 Suppl 1: S1-S266.

Nguyen-Khoa T, Massy ZA, de Bandt JP, Kebede M, Salama L, Lambrey G, Witko- Sarsat V, Drüeke TB, Lacour B, Thévenin M: Oxidative stress and hemodialysis: role of inflammation and duration of dialysis treatment.Nephrol Dial Transplant 2001; 16: 335-40

Salimi S , Firoozrai M, Nourmohammadi I, Shabani M , Mohebbi A .Endothelial nitric oxide synthase gene intron 4 VNTR polymorphism in patients with coronary artery disease in Iran Indian J Med Res 2006; 124:683-8 
Schmidt HH, Walter U. NO at work. Cell 1994; 78: 919-925.

Schmidt RJ, Baylis C. Total nitric oxide production is low in patients with chronic renal disease. Kidney Int 2000; 58:1261-1266 (only 2 authors)

Tang FY, Liu FY, Xie XW. Association of angiotensin-converting enzyme and endothelial Nitric Oxide synthase gene polymorphisms with vascular disease in ESRD patients in a Chinese population. Mol Cell Biochem. 2008 Dec;319(1-2):33-39.

Thaha M, Pranawa, Yogiantoro M, Sutjipto, Sunarjo, Tanimoto M, Gohda T, Tomino Y.Association of endothelial nitric oxide synthase Glu298Asp polymorphism with end-stage renal disease. Clin Nephrol. 2008 Aug;70(2):144-154.

Thibaud D, Philippe R, Ajay M, Emmanuel C, Isabelle M, Hassenfuss G, Marotti F, Samuel JL, Heymes C. Increased neuronal nitric oxide synthase derived NO production in the failing human heart. Lancet 2004; 363: 1365-7

Tolins JP, Palmer RM, Moncada S, Raij L. Role of endothelium-derived relaxing factor in regulation of renal hemodynamic responses. Am J Physiol 1990; 258: 655-662.

Tripathi G, Sharma RK, Baburaj VP, Sankhwar SN, Jafar T, Agrawal S. Genetic risk factors for renal failure among north Indian ESRD patients. Clin Biochem. 2008 May;41(78):525-31.

Tsikas D. Colourimetric assay of Nitric oxide level. Free Radic Res 2005; 39:797- ?

Tsukada T, Yokoyama K, Arai T Hara S, Yamada A, Kawaguchi Y, Hosoya T, Igari J et al.. Evidence of association of the ecNOS gene polymorphism with plasma NO metabolite levels in humans. Biochem Biophys Res Commun 1998; 245: 190-193

Wang Y, Kikuchi S, Suzuki H, Nagase S, Koyama A. Endothelial nitric oxide synthase gene polymorphism in intron 4 affects the progression of renal failure in non-diabetic renal diseases. Nephrol Dial Transplant 1999; 14: 2989-2902.

Wasson S, Govindarajan G, Reddy HK, Flaker G. The role of nitric oxide and vasopressin in refractory right heart failure. J Cardiovascpharm Ther 2004; 9:9-11

Y.Yoon, J Song, S. Ho Hong, Kim J Q. Plasma nitric Oxide concentrations and nitric oxide synthase gene polymorphisms in coronary artery disease. Clinical Chemistry 2000; 46(10): 1626-1630( only 4 authors).

Yemişçi M, Sinici I, Ozkara HA, et al. Protective role of $27 \mathrm{bp}$ repeat polymorphism in intron 4 of eNOS gene in Lacunar Infraction. Free Radic Res 2009; 43(3): 272-9

Yilmaz E, Mir S, Berdeli A.Endothelial nitric oxide synthase (eNOS) gene polymorphism in early term chronic allograft nephropathy. Transplant Proc. 2009 Dec;41(10):43614365 . 


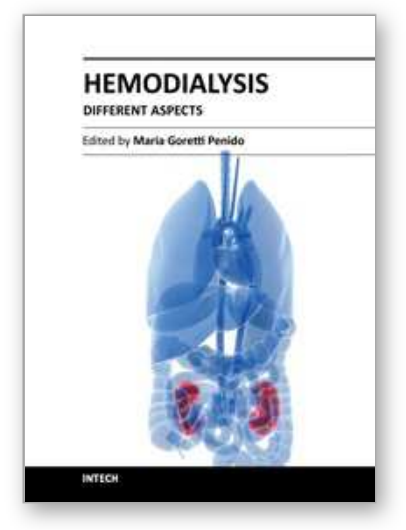

\author{
Hemodialysis - Different Aspects \\ Edited by Prof. Maria Goretti Penido
}

ISBN 978-953-307-315-6

Hard cover, 321 pages

Publisher InTech

Published online 14, November, 2011

Published in print edition November, 2011

The book provides practical and accessible information on all aspects of hemodialysis, with emphasis on dayto-day management of patients. It is quite comprehensive as it covers almost all the aspects of hemodialysis. In short it is a valuable book and an essential aid in the dialysis room.

\title{
How to reference
}

In order to correctly reference this scholarly work, feel free to copy and paste the following:

Manal F. Elshamaa, Samar Sabry, Ahmed Badr, Eman A. Elghoroury, Soulaf Kamel and Gamila Elsaied (2011). Plasma Total Nitric Oxide and Endothelial Constitutive Nitric Oxide Synthase (ecNOS) Inron 4 Gene Polymorphism: A Study in Children with Chronic Kidney Disease, Hemodialysis - Different Aspects, Prof. Maria Goretti Penido (Ed.), ISBN: 978-953-307-315-6, InTech, Available from:

http://www.intechopen.com/books/hemodialysis-different-aspects/plasma-total-nitric-oxide-and-endothelialconstitutive-nitric-oxide-synthase-ecnos-inron-4-gene-poly

\section{INTECH}

open science | open minds

\section{InTech Europe}

University Campus STeP Ri

Slavka Krautzeka 83/A

51000 Rijeka, Croatia

Phone: +385 (51) 770447

Fax: +385 (51) 686166

www.intechopen.com

\section{InTech China}

Unit 405, Office Block, Hotel Equatorial Shanghai

No.65, Yan An Road (West), Shanghai, 200040, China 中国上海市延安西路65号上海国际贵都大饭店办公楼 405 单元

Phone: +86-21-62489820

Fax: $+86-21-62489821$ 
(C) 2011 The Author(s). Licensee IntechOpen. This is an open access article distributed under the terms of the Creative Commons Attribution 3.0 License, which permits unrestricted use, distribution, and reproduction in any medium, provided the original work is properly cited. 